\title{
Article \\ Sesquiterpenes and Monoterpenes from the Leaves and Stems of Illicium simonsii and Their Antibacterial Activity
}

\author{
Huijuan $\mathrm{Li}^{1,2}$, Xinghui Song ${ }^{1,2}$, Huiru $\mathrm{Li}^{3}$, Lifei Zhu ${ }^{2}$, Shengbo Cao ${ }^{1, *}$ and Jifeng Liu ${ }^{4, *}$ (D) \\ 1 State Key Laboratory of Agricultural Microbiology, Huazhong Agricultural University, Wuhan 430070, China; \\ lihj2022@126.com (H.L.); sxh811520@163.com (X.S.) \\ 2 School of Veterinary Medicine, Henan University of Animal Husbandry and Economy, \\ Zhengzhou 450046, China; zhao_fx0309@163.com \\ 3 Eastern China Conservation Centre for Wild Endangered Plant Resources, Shanghai Chenshan Botanical \\ Garden, Shanghai 201602, China; wwwlihuiru@163.com \\ 4 School of Pharmaceutical Science, Zhengzhou University, Zhengzhou 450001, China \\ * Correspondence: sbcao@mail.hzau.edu.cn (S.C.); liujf2009y@126.com (J.L.)
}

check for updates

Citation: Li, H.; Song, X.; Li, H.; Zhu, L.; Cao, S.; Liu, J. Sesquiterpenes and Monoterpenes from the Leaves and Stems of Illicium simonsii and Their Antibacterial Activity. Molecules 2022, 27, 1115. https://doi.org/ 10.3390/molecules 27031115

Academic Editor: René Csuk

Received: 8 December 2021

Accepted: 13 January 2022

Published: 8 February 2022

Publisher's Note: MDPI stays neutral with regard to jurisdictional claims in published maps and institutional affiliations.

Copyright: (c) 2022 by the authors. Licensee MDPI, Basel, Switzerland. This article is an open access article distributed under the terms and conditions of the Creative Commons Attribution (CC BY) license (https:// creativecommons.org/licenses/by/ $4.0 /)$.

\begin{abstract}
Two undescribed ether derivatives of sesquiterpenes, 1-ethoxycaryolane-1, 9 $\beta$-diol (1) and 2-ethoxyclovane-2 $\beta, 9 \alpha$-diol (3), and one new monoterpene glycoside, p-menthane- $1 \alpha, 2 \alpha, 8$-triol-4-O$\beta$-D-glucoside (5), were obtained, together with eight known compounds from the stems and leaves of I. simonsii. Their structures were elucidated by spectroscopic methods. Compounds 1-11 were evaluated for their potency against Staphylococcus aureus and clinical methicillin-resistant S. aureus (MRSA). Among them, compound 3 was weakly active against $S$. aureus ( $\mathrm{MIC}=128 \mu \mathrm{g} / \mathrm{mL}$ ), and compounds 6 and 7 exhibited good antibacterial activity against $S$. aureus and MRSA (MICs $=2-8 \mu \mathrm{g} / \mathrm{mL}$ ). A primary mechanism study revealed that compounds 6 and 7 could kill bacteria by destroying bacterial cell membranes. Moreover, compounds 6 and 7 were not susceptible to drug resistance development.
\end{abstract}

Keywords: Illicium simonsii; sesquiterpene; monoterpene; antibacterial; MRSA

\section{Introduction}

Staphylococcus aureus is one of the most devastating bacterial pathogens that can cause serious infections in both humans and animals [1]. The great challenge in the treatment of S. aureus infections is the appearance of methicillin-resistant S. aureus (MRSA) strains, which are not only developing resistance to conventional antibiotics, including $\beta$-lactams, macrolides, lincosamides, aminoglycosides and tetracyclines, but are also developing resistance to anti-MRSA antibiotics such as vancomycin, teicoplanin, linezolid and daptomycin [2-4]. There is an urgent need to discover and develop novel antibacterial compounds with therapeutic ability against these drug-resistant bacterial strains.

Illicium simonsii Maxim (Illiciaceae) is an evergreen tree or shrub and is distributed mainly in Southeast Asia [5]. Previous investigations on this plant have revealed that it is a rich source of essential oil, sesquiterpenoids, lignans and $C_{6}-C_{3}$ compounds [5-7].

According to our previous study, triphenyl-sesquineolignans isolated from I. simonsii exhibited good antibacterial activity against S. aureus and MRSA [8,9], which inspired us to further explore and confirm the antibacterial constituents of I. simonsii. In this paper, the isolation and structural elucidation of eleven terpenoids including three new compounds from I. simonsii were reported. In addition, their antibacterial activity was evaluated and the primary mechanism of action of the most active compounds, 6 and 7 , was further investigated.

\section{Results}

2.1. Chemistry

Compound 1, a colorless gum, showed an absorption band for hydroxyl $\left(3416 \mathrm{~cm}^{-1}\right)$ in the IR experiment, and the HRESIMS data $\left(\mathrm{m} / z=289.2144[\mathrm{M}+\mathrm{Na}]^{+}\right.$, calcd. for 
$\mathrm{C}_{17} \mathrm{H}_{30} \mathrm{O}_{2} \mathrm{Na}$, 289.2144) indicate the molecular formula to be $\mathrm{C}_{17} \mathrm{H}_{30} \mathrm{O}_{2}$. The ${ }^{1} \mathrm{H}$ NMR spectrum displayed characteristic signals due to three tertiary methyl groups $\left(\delta_{\mathrm{H}} 0.98(\mathrm{~s}\right.$, $\left.\mathrm{H}_{3}-13\right), 0.10\left(\mathrm{~s}, \mathrm{H}_{3}-14\right)$ and $\left.0.91\left(\mathrm{~s}, \mathrm{H}_{3}-15\right)\right)$, and one ethoxy unit $\left(\delta_{\mathrm{H}} 3.46-3.49\left(2 \mathrm{H}, \mathrm{m}, \mathrm{H}-1^{\prime}\right)\right.$ and $\left.1.14\left(3 \mathrm{H}, \mathrm{t}, J=7.0 \mathrm{~Hz}, \mathrm{H}_{3}-2^{\prime}\right)\right)$. The ${ }^{13} \mathrm{C}$ NMR showed the presence of three tertiary methyl groups, five methylene groups, three methine groups (including one oxygenated carbon $\delta_{C} 72.6(C-9)$ ), three quaternary carbons (including one oxygenated carbon $\delta_{C} 75.3$ $(C-1))$ and an ethoxy group $\left(\delta_{C} 57.3\right.$ and 16.0) (Table 1). The above NMR data of compound 1 are similar to those of caryolane-1,9 $9 \beta$-diol (2) [10], except the additional signals of an ethoxy unit and the downfield shift of $C-1\left(\delta_{C} 75.3\right)$. These characteristic signals indicated that one ethoxy unit should be attached at $\mathrm{C}-1$, which was further confirmed by the cross-peak between $\mathrm{H}-1^{\prime} / \mathrm{C}-1$ in the HMBC spectrum (Figure 1). Compound 1 has the same relative configuration as compound $\mathbf{2}$ according to the ROESY experiment. Thus, the structure of compound 1 was elucidated as 1-ethoxycaryolane-1, 9 $\beta$-diol.

Table 1. ${ }^{1} \mathrm{H}$ NMR and ${ }^{13} \mathrm{C}$ NMR spectroscopic data of compounds $\mathbf{1}$ and $\mathbf{3}$ in $\mathrm{CDCl}_{3}$.

\begin{tabular}{|c|c|c|c|c|}
\hline \multirow{2}{*}{ Position } & \multicolumn{2}{|c|}{1} & \multicolumn{2}{|c|}{3} \\
\hline & $\delta_{\mathrm{H}}($ Multi, $J$ in $\mathrm{Hz})$ & $\delta_{\mathrm{C}}$ (Multi) & $\delta_{\mathrm{H}}($ Multi, $J$ in $\mathrm{Hz})$ & $\delta_{\mathrm{C}}$ (Multi) \\
\hline 1 & - & $75.3(\mathrm{~s})$ & - & $44.2(\mathrm{~s})$ \\
\hline 2 & $2.09-2.14(\mathrm{~m})$ & $38.8(\mathrm{~d})$ & $3.42(\mathrm{dd}, 10.6,5.5)$ & $88.1(\mathrm{~d})$ \\
\hline $3 \alpha$ & $1.61(\mathrm{~d}, 9.3)$ & \multirow{2}{*}{$36.3(t)$} & $1.66(\mathrm{dd}, 11.8,5.6)$ & \multirow{2}{*}{$45.0(\mathrm{t})$} \\
\hline $3 \beta$ & $1.48-1.51$ (overlap) & & $1.49(\mathrm{dd}, 11.4,11.0)$ & \\
\hline 4 & - & $35.2(\mathrm{~s})$ & - & $36.9(\mathrm{~s})$ \\
\hline 5 & $1.90-1.93(\mathrm{~m})$ & $44.9(\mathrm{~d})$ & $1.40-1.42$ (overlap) & $50.6(d)$ \\
\hline $6 \alpha$ & $1.51-1.53(\mathrm{~m})$ & \multirow{2}{*}{$20.9(\mathrm{t})$} & $1.40-1.42$ (overlap) & \multirow{2}{*}{$20.6(t)$} \\
\hline $6 \beta$ & $1.31-1.36(\mathrm{~m})$ & & $1.29-1.32(\mathrm{~m})$ & \\
\hline $7 \alpha$ & $1.43-1.45(\mathrm{~m})$ & \multirow{2}{*}{$35.9(t)$} & $1.36-1.39(\mathrm{~m})$ & \multirow{2}{*}{$33.1(t)$} \\
\hline $7 \beta$ & $1.12-1.16(\mathrm{~m})$ & & $1.09-1.11(\mathrm{~m})$ & \\
\hline 8 & - & $39.0(\mathrm{~s})$ & - & $34.8(\mathrm{~s})$ \\
\hline 9 & $3.44-3.46(\mathrm{~m})$ & $72.6(\mathrm{~d})$ & 3.31 (br s) & $75.3(d)$ \\
\hline $10 \alpha$ & $1.76-1.80(\mathrm{~m})$ & \multirow{2}{*}{$28.0(\mathrm{t})$} & $1.58-1.61$ (overlap) & \multirow{2}{*}{$26.0(\mathrm{t})$} \\
\hline $10 \beta$ & $1.96-2.01(\mathrm{~m})$ & & $1.95-2.01(\mathrm{~m})$ & \\
\hline $11 \alpha$ & $1.73(\mathrm{dd}, 12.2,5.5)$ & \multirow{2}{*}{$29.2(\mathrm{t})$} & $1.69(\mathrm{dd}, 13.7,4.7)$ & \multirow{2}{*}{$26.7(t)$} \\
\hline $11 \beta$ & $1.61-1.63(\mathrm{~m})$ & & $1.11-1.13(\mathrm{~m})$ & \\
\hline $12 \alpha$ & 1.46-1.51 (overlap) & \multirow{2}{*}{$41.2(\mathrm{t})$} & $0.98-1.00(\mathrm{~m})$ & \multirow{2}{*}{$36.6(t)$} \\
\hline $12 \beta$ & 1.46-1.51 (overlap) & & $1.58-1.61$ (overlap) & \\
\hline 13 & $0.98(\mathrm{~s})$ & $20.7(q)$ & $0.85(\mathrm{~s})$ & $25.4(q)$ \\
\hline 14 & $0.10(\mathrm{~s})$ & $30.4(\mathrm{q})$ & $1.02(\mathrm{~s})$ & $31.3(\mathrm{q})$ \\
\hline 15 & $0.91(\mathrm{~s})$ & $26.8(\mathrm{q})$ & $0.96(\mathrm{~s})$ & $28.4(\mathrm{q})$ \\
\hline $1^{\prime}$ & $3.46-3.49(\mathrm{~m})$ & $57.3(\mathrm{t})$ & $3.47-3.55(\mathrm{~m})$ & $65.8(\mathrm{t})$ \\
\hline $2^{\prime}$ & $1.14(t, 7.0)$ & $16.0(q)$ & $1.71(t, 7.0)$ & $15.7(q)$ \\
\hline
\end{tabular}




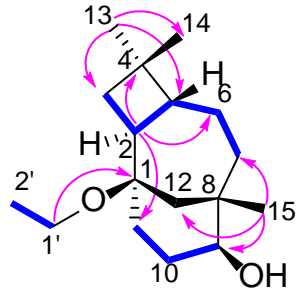

1

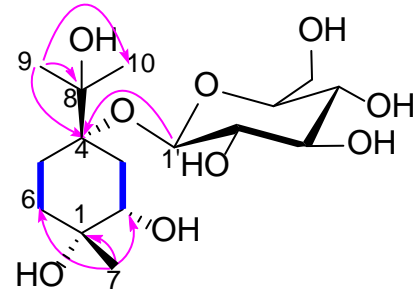

5

8<smiles>CC(C)C1=CC[C@]2(C)[C@@H](O)CC[C@H](C)[C@H]2C1</smiles>

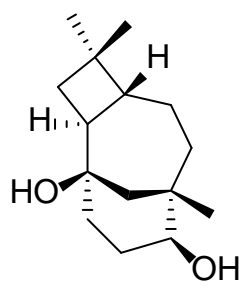

2

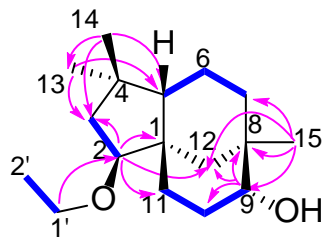

3

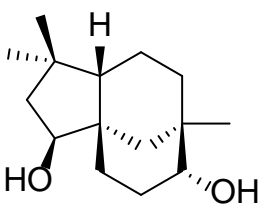

4<smiles>CC1(C)C2CCC1(OC(=O)/C=C\c1ccc(O)cc1)CC2</smiles>

7

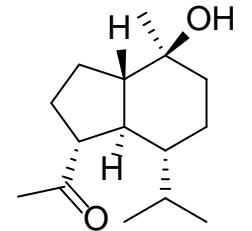

9<smiles>CC1=CC(=O)CC(C)(C)[C@@]1(O)/C=C/C(C)=C\C(=O)O</smiles>

10<smiles>CC(=O)/C=C/[C@]1(O)[C@@](C)(O)C[C@H](O)C[C@]1(C)O</smiles>

11

Figure 1. The structure of compounds 1-11; Selected HMBC $(\rightarrow)$ and ${ }^{1} \mathrm{H}^{-1} \mathrm{H}$ COSY $(-)$ correlations of 1, 3 and 5 .

Compound 3 was isolated as colorless gum, and its molecular formula was determined to be $\mathrm{C}_{17} \mathrm{H}_{30} \mathrm{O}_{2}$ based on HRESIMS $\left(m / z=289.2136[\mathrm{M}+\mathrm{Na}]^{+}\right.$, calcd. for $\mathrm{C}_{17} \mathrm{H}_{30} \mathrm{O}_{2} \mathrm{Na}$, 289.2138). The IR spectrum of compound 3 showed the presence of a hydroxyl group at $3382 \mathrm{~cm}^{-1}$. Upon comparison of the ${ }^{1} \mathrm{H}-\mathrm{NMR}$ and ${ }^{13} \mathrm{C}-\mathrm{NMR}$ spectrum with those of clovane-2 $\beta, 9 \alpha$-diol (4) [11], compound 3 exhibited additional signals of an ethoxy unit $\left(\left(\delta_{C}\right.\right.$ 65.8 and $15.7 ; \delta_{\mathrm{H}} 3.47-3.55(2 \mathrm{H}, \mathrm{m})$ and $1.71(3 \mathrm{H}, \mathrm{t}, J=7.0 \mathrm{~Hz})$ ) (Table 1$)$. The ethoxy unit was found to be attached at C-2 by the observed downfield shift $\left(\delta_{C} 88.1, C-2\right)$ and further confirmed by the cross-peak between H-1' /C-2 in the HMBC spectrum (Figure 1). The relative configuration of 3 was the same as that of compound 4 according to the ROESY experiment. Thus, the structure of compound 3 was elucidated as 2-ethoxyclovane-2 $\beta$, $9 \alpha$-diol.

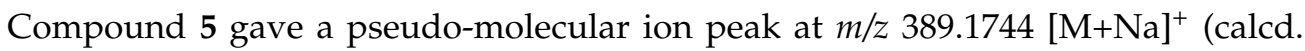
for $\mathrm{C}_{16} \mathrm{H}_{30} \mathrm{O}_{9} \mathrm{Na}$, 389.1782) in the HRESIMS spectrum and exhibited a strong absorption band for hydroxyl groups $\left(3416.6 \mathrm{~cm}^{-1}\right)$ in the IR spectrum. The ${ }^{13} \mathrm{C}$ NMR data revealed 16 carbon signals, consisting of a monoterpene skeleton and a D-glucopyranosyl moiety. The ${ }^{1} \mathrm{H}$ NMR signals of anomeric protons of the D-glucopyranosyl moiety at $\delta_{\mathrm{H}} 4.37(1 \mathrm{H}$, $\mathrm{d}, J=7.7 \mathrm{~Hz}, \mathrm{H}-1^{\prime}$ ) are consistent with the configuration for $\beta$-D-glucose. The NMR data of aglycone moiety of 5 were similar with those of $(1 S, 2 S, 4 R)$-p-menthane-1,2,8-triol [12], except for the appearance of a quaternary carbon signal at $\delta c 76.3(\mathrm{C}-4)$ derived from the connection with the glucose moiety (Table 2). This assignment was further confirmed by the HMBC correlations between $\mathrm{H}-1^{\prime}$ with $\mathrm{C}-4$ (Figure 1). The observation of correlations $\mathrm{H}_{3}-7 / \mathrm{H}-2, \mathrm{H}-2 / \mathrm{H}_{\beta}-3, \mathrm{H}_{\beta}-3 / \mathrm{H}-9$ and $\mathrm{H} \alpha-3 / \mathrm{H}-1^{\prime}$ in the NOESY experiment confirmed the relative configuration of compound 5, as shown in Figure 1. Thus, the structure of 5 was established as $\mathrm{p}$-menthane- $1 \alpha, 2 \alpha, 8$-triol-4-O- $\beta$-D-glucoside. 
Table 2. ${ }^{1} \mathrm{H}$ NMR and ${ }^{13} \mathrm{C}$ NMR spectroscopic data of compound 5 in $\mathrm{CD}_{3} \mathrm{OD}$.

\begin{tabular}{|c|c|c|c|c|c|}
\hline \multirow{2}{*}{ Position } & \multicolumn{5}{|c|}{5} \\
\hline & $\delta_{\mathrm{H}}($ Multi, $J$ in $\mathrm{Hz})$ & $\delta_{\mathrm{C}}$ (Multi) & Position & $\delta_{\mathrm{H}}($ Multi, $J$ in $\mathrm{Hz})$ & $\delta_{\mathrm{C}}$ (Multi) \\
\hline 1 & - & $72.7(\mathrm{~s})$ & 9 & $1.12(\mathrm{~s})$ & $24.3(\mathrm{q})$ \\
\hline 2 & $3.61-3.64(\mathrm{~m})$ & $71.6(\mathrm{~d})$ & 10 & $1.20(\mathrm{~s})$ & $24.4(q)$ \\
\hline $3 \alpha$ & $1.64-1.67(\mathrm{dd}, 13.3,3.7)$ & \multirow{2}{*}{$37.0(\mathrm{t})$} & \multirow{2}{*}{$1^{\prime}$} & \multirow{2}{*}{$4.37(\mathrm{~d}, 7.7)$} & \multirow{2}{*}{$97.2(\mathrm{~d})$} \\
\hline $3 \beta$ & $2.36-2.40(\mathrm{~m})$ & & & & \\
\hline 4 & - & $76.3(\mathrm{~s})$ & $2^{\prime}$ & $3.01(\mathrm{~m})$ & $73.8(\mathrm{~d})$ \\
\hline $5 \alpha$ & 1.93-2.03 (overlap) & \multirow{2}{*}{$27.1(\mathrm{t})$} & \multirow{2}{*}{$3^{\prime}$} & \multirow{2}{*}{$3.21-3.24(\mathrm{~m})$} & \multirow{2}{*}{$76.9(\mathrm{~d})$} \\
\hline $5 \beta$ & $1.50-1.56(\mathrm{~m})$ & & & & \\
\hline $6 \alpha$ & $1.75-1.80(\mathrm{~m})$ & \multirow{2}{*}{$27.2(\mathrm{t})$} & \multirow{2}{*}{$4^{\prime}$} & \multirow{2}{*}{$3.15-3.18(\mathrm{~m})$} & \multirow{2}{*}{$70.2(d)$} \\
\hline $6 \beta$ & 1.93-2.03 (overlap) & & & & \\
\hline 7 & $0.94(\mathrm{~s})$ & $22.4(\mathrm{q})$ & $5^{\prime}$ & $3.12-3.15(\mathrm{~m})$ & $76.3(d)$ \\
\hline \multirow{2}{*}{8} & \multirow{2}{*}{-} & \multirow{2}{*}{$76.5(\mathrm{~s})$} & $6^{\prime} \mathrm{a}$ & $3.72-3.74(\mathrm{dd}, 12.0,2.3)$ & \multirow{2}{*}{$61.4(t)$} \\
\hline & & & $6^{\prime} b$ & $3.53-3.56(\mathrm{dd}, 11.9,5.6)$ & \\
\hline
\end{tabular}

Data were recorded at $400 \mathrm{MHz}$ for proton and at $100 \mathrm{MHz}$ for carbon. Data assignments were based on HSQC and HMBC experiments.

Eight known compounds were identified as caryolane-1,9 $\beta$-diol (2), clovane- $2 \alpha, 9 \beta$-diol (4) [10], pressafonin A (6), pressafonin B (7) [13], oplodiol (8) [14], ent-oplopanone (9) [15], abscisic acid (10) [16] and (3S,5R,6S,7E)-3,5,6-trihydroxy-7-megastigmen-9-one (11) [17] by comparison of their NMR spectroscopic data with those reported in the literature (Supporting Information).

\subsection{Antibacterial Activity}

\subsubsection{Antimicrobial Activity Test of the I. simonsii Extract}

The antimicrobial activity of the ethanol extract of $I$. simonsii was first determined for S. aureus ATCC 29213, Bacillus. subtilis ATCC 6633 and Enterococcus faecalis ATCC 29212. The zones of inhibition of $10 \mu \mathrm{g} /$ disc of I. simonsii ethanol extract were $8.34 \mathrm{~mm}$ for S. aureus, $8.34 \mathrm{~mm}$ for B. subtilis and $7.70 \mathrm{~mm}$ for E. faecalis (Supporting Information). It is evident that the I. simonsii extract might have active compounds responsible for the antimicrobial activity.

\subsubsection{Determination of Minimum Inhibitory Concentration (MIC)}

The antimicrobial activity of compounds 1-11 was tested against both S. aureus (Grampositive) and Escherichia coli (Gram-negative), and their MIC values are shown in Table 3. Compounds 6 and 7 exhibited good antibacterial activity against $S$. aureus with MIC $=4$ and $8 \mu \mathrm{g} / \mathrm{mL}$, respectively. Compound 3 was weakly active against $S$. aureus with $\mathrm{MIC}=128 \mu \mathrm{g} / \mathrm{mL}$. However, all compounds did not exhibit any activity against $E$. coli at tested concentrations lower than $128 \mu \mathrm{g} / \mathrm{mL}$. The most active compounds, 6 and 7 , were further evaluated against 10 clinical MRSA strains using the same method. As shown in Table 4, the range of MIC values of compounds 6 and 7 was $2-8 \mu \mathrm{g} / \mathrm{mL}$.

Table 3. MIC $(\mu \mathrm{g} / \mathrm{mL})$ values of compounds 1-11 against $S$. aureus and E. coli in vitro.

\begin{tabular}{|c|c|c|c|c|c|c|c|c|c|c|c|c|c|}
\hline & 1 & 2 & 3 & 4 & 5 & 6 & 7 & 8 & 9 & 10 & 11 & $\operatorname{VAN}^{c}$ & MER $^{d}$ \\
\hline S. $a^{\mathrm{a}}$ & $>128$ & $>128$ & 128 & $>128$ & $>128$ & 4 & 8 & $>128$ & $>128$ & $>128$ & $>128$ & 2 & $\mathrm{ND}^{\mathrm{e}}$ \\
\hline E. $c^{\mathrm{b}}$ & $>128$ & $>128$ & $>128$ & $>128$ & $>128$ & $>128$ & $>128$ & $>128$ & $>128$ & $>128$ & $>128$ & $\mathrm{ND}^{\mathrm{e}}$ & 0.0625 \\
\hline
\end{tabular}

${ }^{a}$ S. a.: Staphylococcus aureus ATCC $29213 ;{ }^{b}$ E. c: Escherichia coli ATCC 25922; ${ }^{c}$ VAN: vancomycin; ${ }^{\mathrm{d}}$ MER: meropenem; ${ }^{\mathrm{e}} \mathrm{ND}$ : not determined. Each test was repeated three times. 
Table 4. MIC $(\mu \mathrm{g} / \mathrm{mL})$ values of compounds 6 and 7 against clinical MRSA strains in vitro.

\begin{tabular}{|c|c|c|c|c|c|c|c|c|c|c|}
\hline \multirow{2}{*}{ Compound } & \multicolumn{10}{|c|}{ Clinical Isolates of MRSA } \\
\hline & M-1 & M-2 & M-3 & M-4 & M-5 & M-6 & M-7 & M-8 & M-9 & M-10 \\
\hline 6 & 2 & 4 & 4 & 2 & 4 & 2 & 4 & 4 & 4 & 4 \\
\hline 7 & 4 & 8 & 8 & 4 & 8 & 4 & 8 & 8 & 4 & 8 \\
\hline $\operatorname{Van}^{\mathrm{a}}$ & 1 & 1 & 1 & 1 & 1 & 1 & 1 & 1 & 2 & 2 \\
\hline
\end{tabular}

${ }^{a}$ Van: vancomycin, positive control; The experiment was repeated three times.

\subsubsection{Time-Kill Kinetics Assay}

The time-kill kinetics assay of compounds 6 and 7 with different concentrations was carried out against MRSA-3. As shown in Figures 2 and 3, both 6 and 7 showed rapid bactericidal activity. More specifically, the early exponential phase MRSA-3 could be completely eradicated by compound 6 (at $8 \mu \mathrm{g} / \mathrm{mL}(2 \times \mathrm{MIC})$ and $16 \mu \mathrm{g} / \mathrm{mL}(4 \times \mathrm{MIC})$; Figure $2 \mathrm{a}, \mathrm{c})$ and 7 (at $16 \mu \mathrm{g} / \mathrm{mL}(2 \times \mathrm{MIC})$ and $24 \mu \mathrm{g} / \mathrm{mL}(3 \times \mathrm{MIC})$; Figure 3a,c) within $1-2 \mathrm{~h}$, and the growth of the stationary exponential phase MRSA-3 was also effectively prevented by compounds 6 (at $8 \mu \mathrm{g} / \mathrm{mL}$ and $16 \mu \mathrm{g} / \mathrm{mL}$; Figure 2b,d) and 7 (at $16 \mu \mathrm{g} / \mathrm{mL}$ and $24 \mu \mathrm{g} / \mathrm{mL}$; Figure $3 \mathrm{~b}, \mathrm{~d})$, respectively.
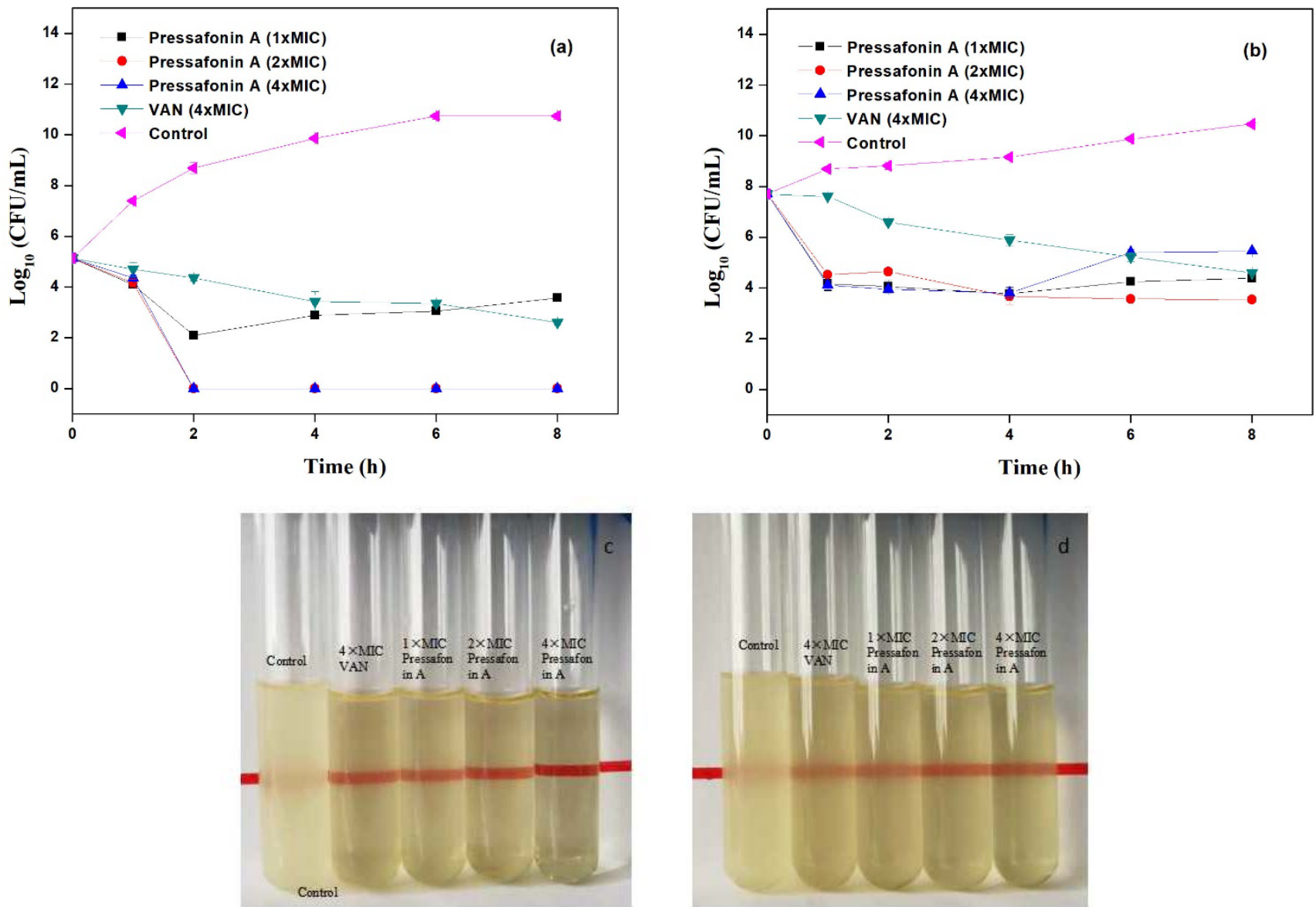

Figure 2. Time-dependent killing of MRSA-3 by compound 6. (a,c) MASA-3 was grown to early exponential phase and was challenged with 6 (at $1 \times, 2 \times$ and $4 \times$ MIC) and vancomycin (at $4 \times$ MIC); $(\mathbf{b}, \mathbf{d})$ MASA-3 was grown to stationary exponential phase and was challenged with 6 (at $1 \times, 2 \times$ and $4 \times \mathrm{MIC})$ and vancomycin (at $4 \times \mathrm{MIC}) ;(\mathrm{c}, \mathrm{d})$ the bacterial suspension after treatment with compound 6 for $8 \mathrm{~h}$. The control was treatment with sterile water. 

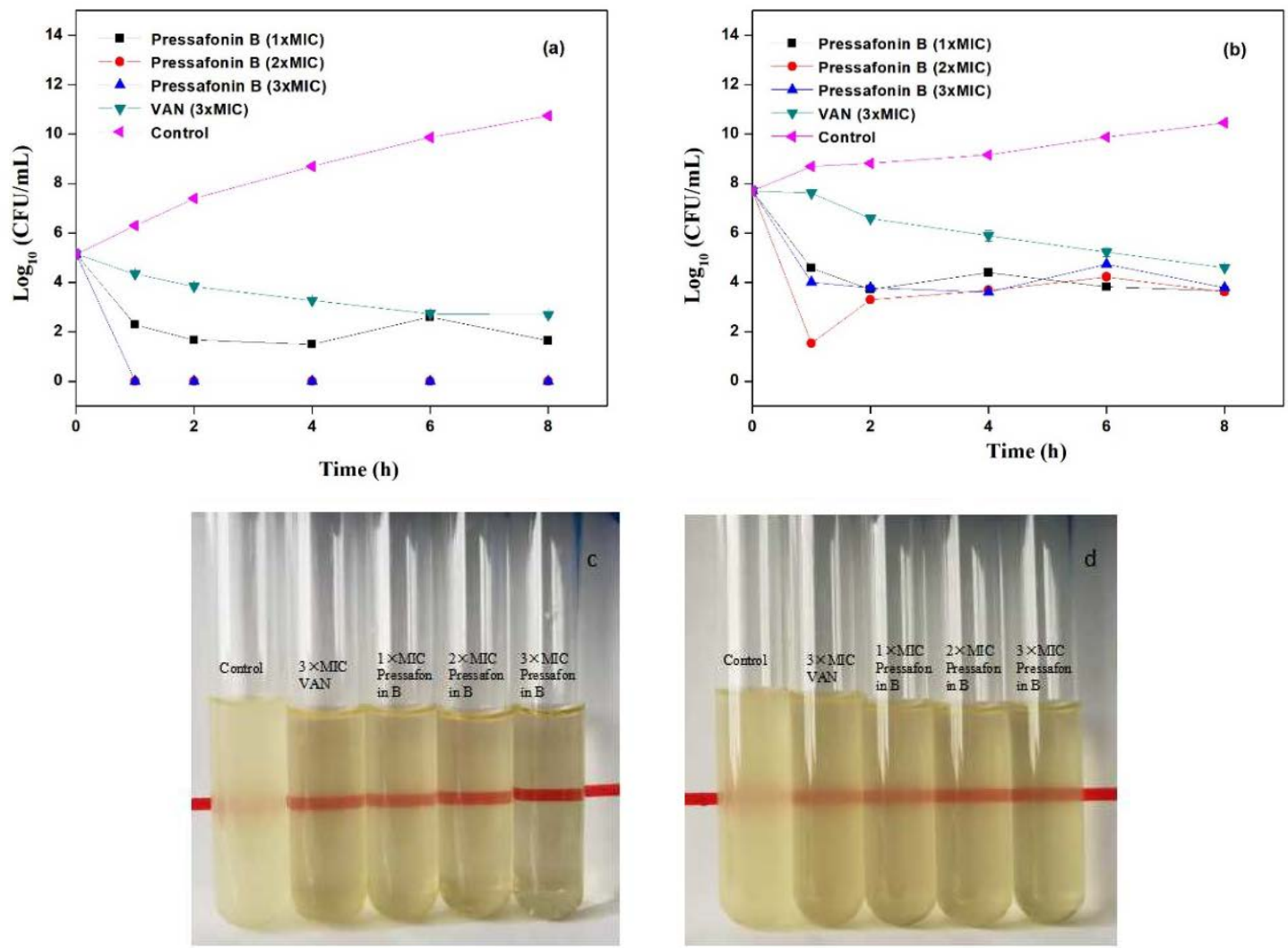

Figure 3. Time-dependent killing of MRSA-3 by compound 7. (a,c) MASA-3 was grown to early exponential phase and was challenged with 7 (at $1 \times, 2 \times$ and $3 \times \mathrm{MIC}$ ) and vancomycin (at $3 \times \mathrm{MIC}$ ); $(\mathbf{b}, \mathbf{d})$ MASA-3 was grown to stationary exponential phase and was challenged with 7 (at $1 \times, 2 \times$ and $3 \times \mathrm{MIC})$ and vancomycin $($ at $3 \times \mathrm{MIC}) ;(\mathbf{c}, \mathbf{d})$ the bacterial suspension after treatment with compound 7 for $8 \mathrm{~h}$. The control was treatment with sterile water.

\subsubsection{Resistance Development Study}

The resistance development studies against S. aureus ATCC 29213 showed that compounds 6 and 7 were unsusceptible to drug resistance development even after 20 passages at subinhibitory concentrations $(2 \mu \mathrm{g} / \mathrm{mL}$ and $4 \mu \mathrm{g} / \mathrm{mL} ; 1 / 2 \times$ MIC, respectively), which demonstrated that it was difficult for $S$. aureus to develop resistance to both compounds, whereas norfloxacin showed an about 64-fold increase in the MIC after 14-16 passages (Figure 4).
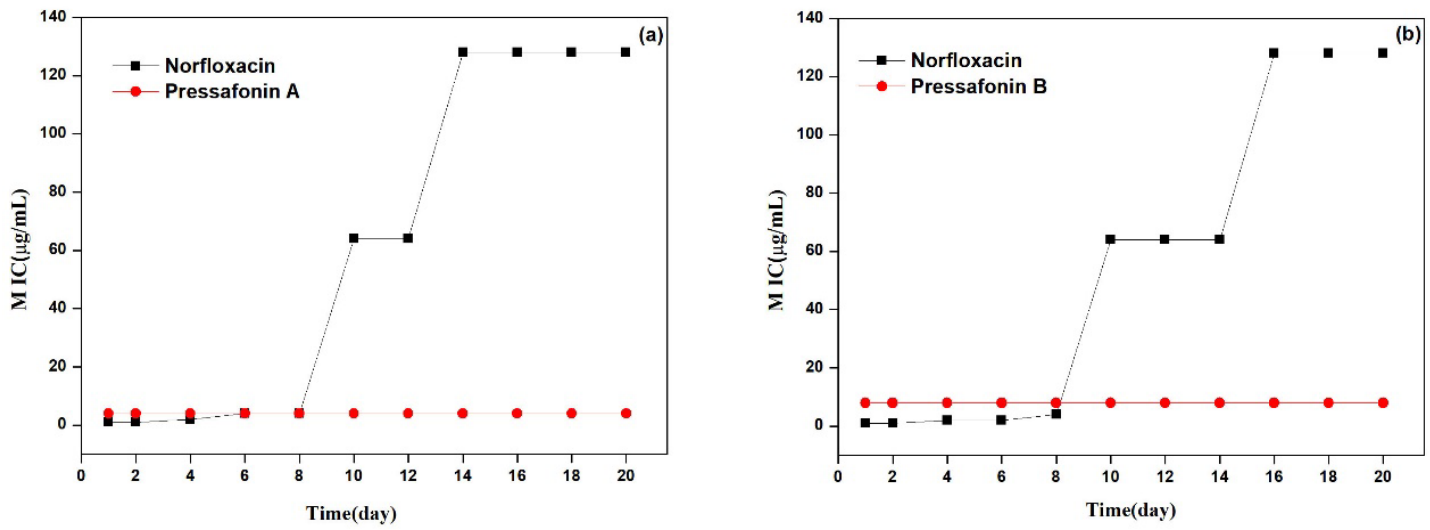

Figure 4. Bacterial resistance study of compounds 6 (a) and 7 (b) against S. aureus ATCC 29213 in the presence of $1 / 2 \times$ MIC levels. Norfloxacin (MIC $=2 \mu \mathrm{g} / \mathrm{mL}$ ) was selected as a positive. 


\subsubsection{Hemolytic Activity}

The preliminary toxicity of compounds 6 and 7 toward mammalian cells was evaluated against lyse red blood cells (RBCs). The $50 \%$ hemolysis concentration $\left(\mathrm{HC}_{50}\right)$ of $\mathbf{6}$ and 7 were approximately $32 \mu \mathrm{g} / \mathrm{mL}(8 \times \mathrm{MIC})$ and $32 \mu \mathrm{g} / \mathrm{mL}(4 \times \mathrm{MIC})$, respectively (Figure 5).
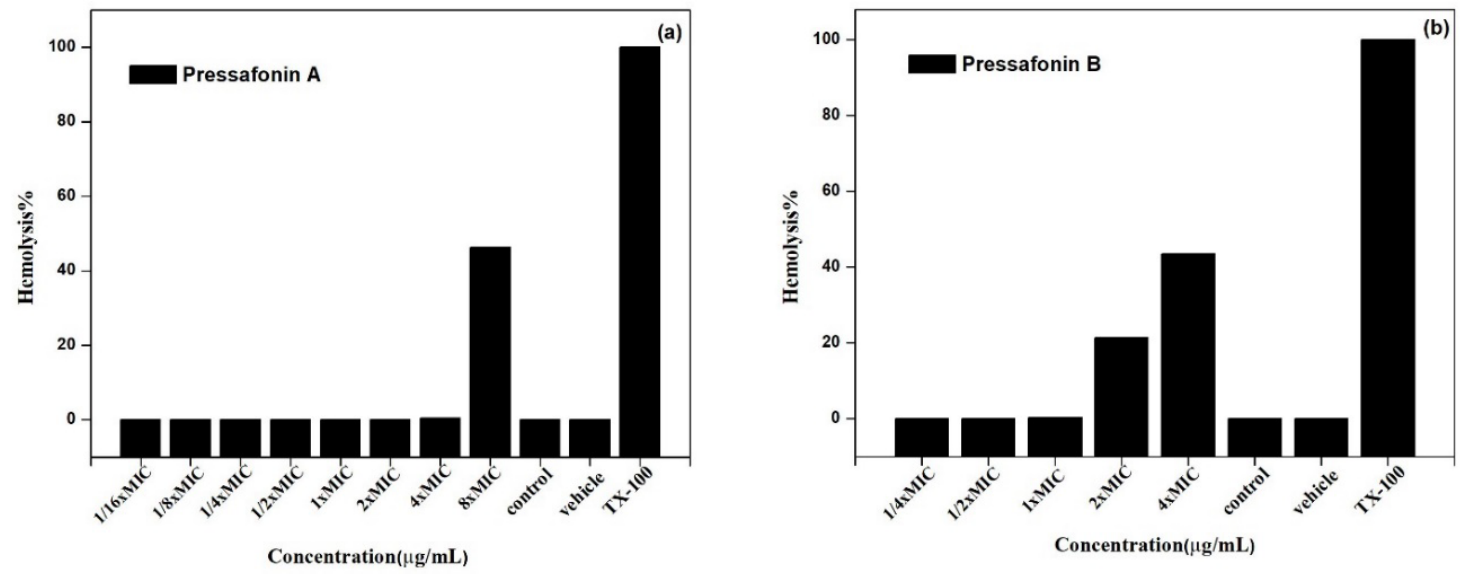

Figure 5. Percentage of hemolysis by 6 (a) and 7 (b) at different concentrations. Control: $50 \mu \mathrm{L}$ of RBCs suspension (5\%), vehicle: $1 \times$ PBS. All experiments were repeated three times.

\subsection{Mode of Antimicrobial Action \\ 2.3.1. SYTOX Green Assay}

In order to explore whether the bactericidal effect of active compounds acts directly on the cell membrane, compound 7 was selected to further investigate the mode of antimicrobial action. Experiments of the SYTOX green assay indicated that when an MRSA-3 bacterial suspension was exposed to $1 \times, 2 \times, 4 \times$ and $8 \times$ MIC of compound 7, it increased the SYTOX green fluorescence emission gradually after $8 \mathrm{~min}$ (Figure 6a). In addition, when the concentration of compound 7 was $8 \times \mathrm{MIC}$, the fluorescence intensity was close to that of the positive control melittin (Figure $6 \mathrm{~b}$ ), while the blank, vancomycin and daptomycin failed to increase the fluorescence intensity under the same conditions. These observations confirmed that compound 7 rapidly disrupted bacterial membranes.
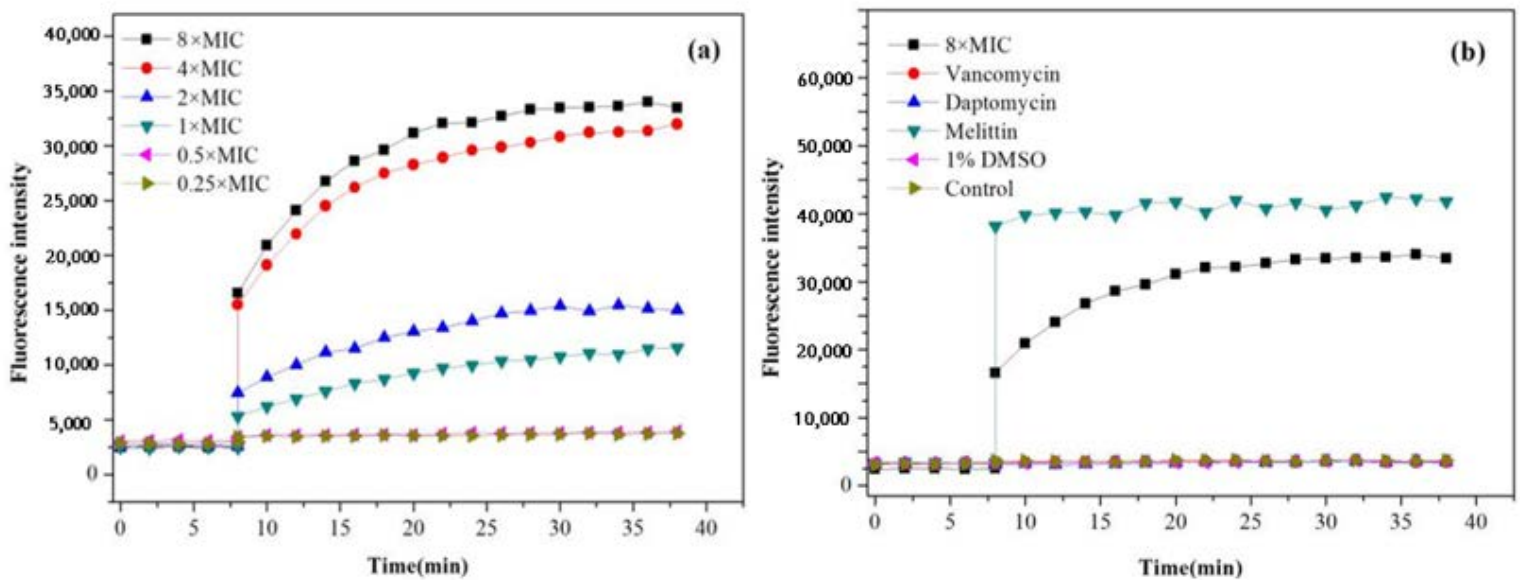

Figure 6. Mode of membrane disruption action of compound 7. (a) Effects of compound 7 with different concentrations on the fluorescence intensity of SYTOX incubated with MRSA-3 at $1 / 4 \times$, $1 / 2 \times, 1 \times, 2 \times, 4 \times$ and $8 \times$ MICs (MIC $=8 \mu \mathrm{g} / \mathrm{mL}$ ); (b) effects of different antibiotics on the SYTOX fluorescence intensity; vancomycin and daptomycin were used as the negative control, and melittin was used as the positive control. The data represent mean values of three independent experiments. 


\subsubsection{Visualization of Bacterial Membrane Permeability}

The influence of compound 7 on the MRSA-3 bacterial membranes was further visualized using 4',6-diamidino-2-phenylindole (DAPI) and propidium iodide (PI), which are typically used to monitor the changes in bacterial viability [18]. As shown in Figure 7, the negative control without compound 7 only displayed blue fluorescence, indicating the intact cell membranes of MRSA-3, while after treatment with compound 7, blue and red fluorescence was observed, suggesting that the cell membranes of MRSA-3 were disrupted by compound 7 .

$\mathrm{D} A \mathrm{PI}$
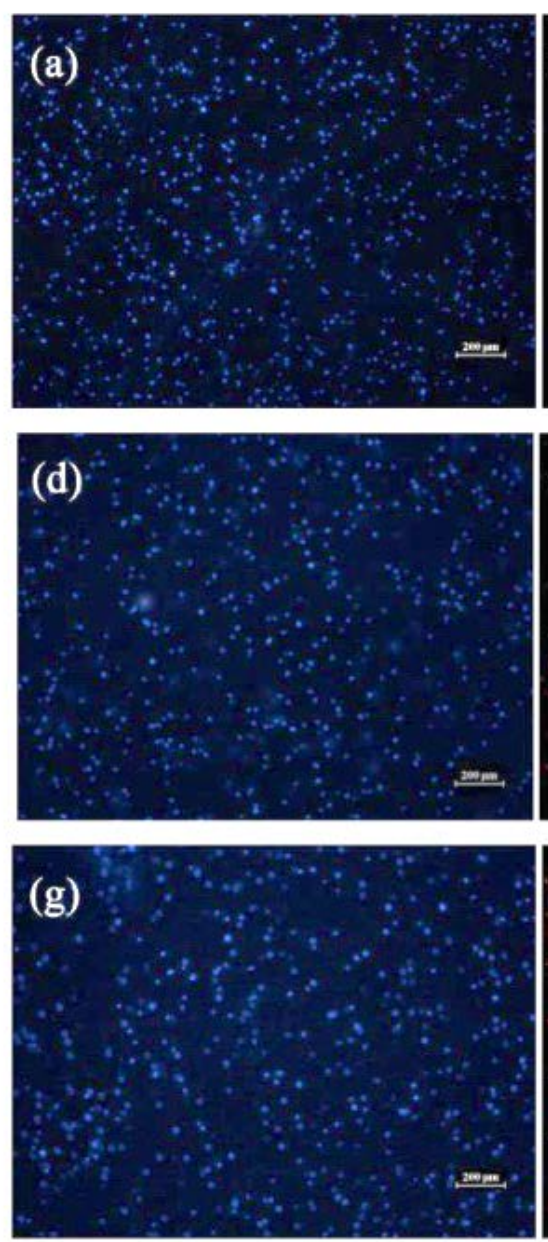

PI
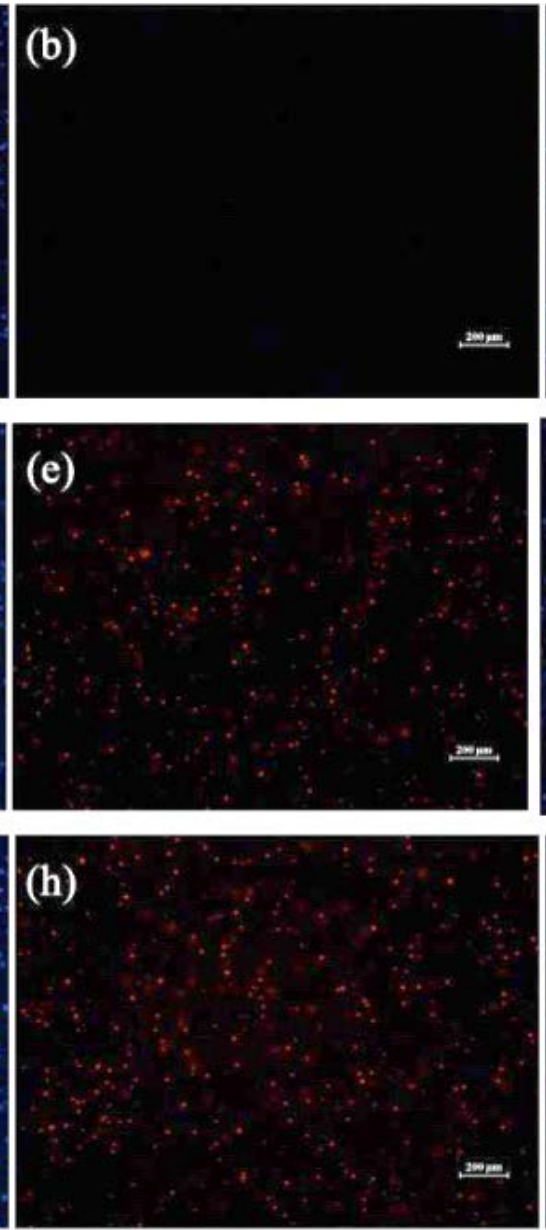

\section{Merged}
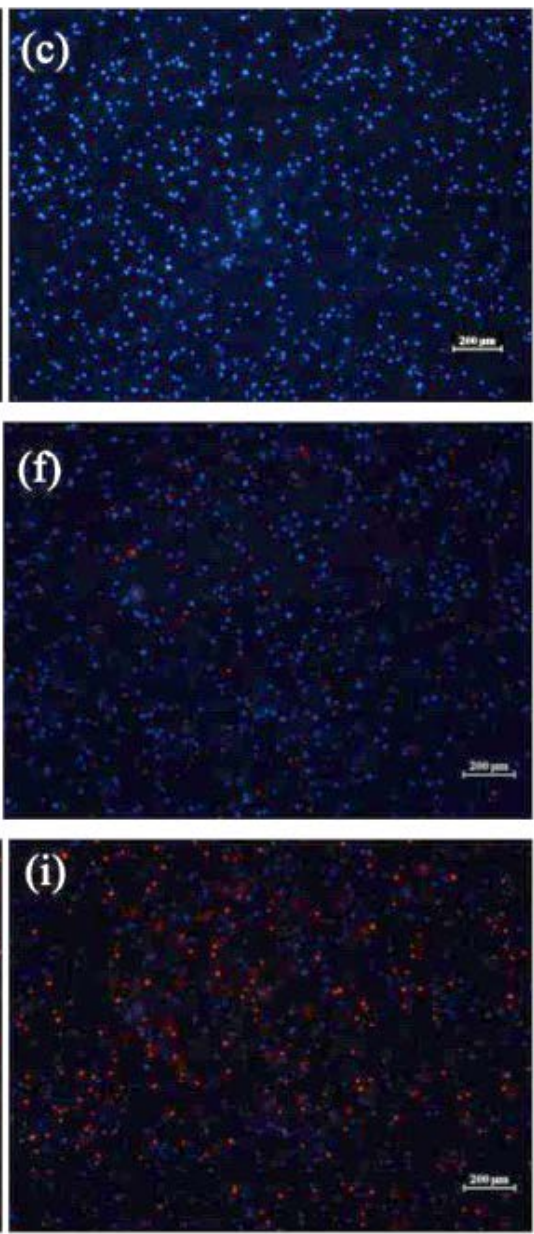

Figure 7. Fluorescence microscopy graphs of DAPI/PI staining of MRSA-3 treated with 2-fold and 4-fold MICs of 7. (a-c) Non-treated with 7 (black control); (d-f) treated with 7 at $2 \times$ MIC; (g-i) treated with 7 at $4 \times$ MIC (scale bar $200 \mu \mathrm{m}$ ).

\section{Discussion}

Several studies have illustrated that essential oils, terpenes and lignans from Illicium species, such as I. verum, I. griffithii, I. wardii, I. angustisepalum and I. simonsii, have potent antimicrobial activity [19-23]. To explain and confirm the antibacterial activity of I. simonsii, bioassay-guided fractionation of the ethanol extract of $I$. simonsii resulted in the isolation of three new natural compounds (1, 3 and $\mathbf{5}$ ) and eight known compounds (Figure 1), in which compounds 3, 6 and 7 are responsible for the antibacterial activity. The most active compounds (-)-bornyl p-coumarate (6) and (-)-bornyl cis-4-hydroxycinnamate (7) showed good activity against $S$. aureus and MRSA, with MIC values of 2-8 $\mathrm{gg} / \mathrm{mL}$. Similar structures exhibiting potent antibacterial activity were reported in previous studies, such as bornyl caffeate, bornyl coumarate [24], bornyl 3', 4'-dimethoxybenzoate and bornyl 3', 4', 5' -tri- 
methoxybenzoate [25]. The antibacterial activity of compound 7 was slightly weaker than that of compound $\mathbf{6}$, which may be attributed to the different configuration of double bonds in their structures. It is worth mentioning that $(+)$-bornyl p-coumarate previously isolated from Piper caninum also exhibited good antibacterial activity with MIC $=2 \mu \mathrm{M}$ [24]. Perhaps the absolute configuration of their structure had no effect on the antibacterial activity. In order to further study the structure-activity relationship, we purchased the compounds (+)-borneol, (-)-borneol, p-coumaric acid and cis-4-hydroxycinnamic acid from Shanghai Aladdin Biochemical Technology Co., Ltd., and tested their antibacterial activity against S. aureus. However, they did not show activity against S. aureus (MICs $>128 \mu \mathrm{g} / \mathrm{mL}$ ). Based on the above research, the esterified products of $( \pm)$-borneol and phenolic compounds can effectively improve their antibacterial activity; the position and the number of phenolic hydroxyl groups are closely related to their antibacterial activity [26]. These understandings could be helpful to propose a strategy for the development and rational design of more potent $( \pm)$-borneol ester-based antimicrobial derivatives.

In this study, the bacterial time-kill kinetics were assessed using clinical isolate MRSA3 with vancomycin as the positive control. Compounds 6 and 7 could efficiently achieve a 4- $\log$ reduction at $4 \times$ MIC and $3 \times$ MIC both at the early exponential and stationary phases of cells within 1-2 h, respectively, whereas vancomycin needed more than $8 \mathrm{~h}$ to achieve this. The rapid antibacterial features of compounds 6 and 7 seem to indicate that their bactericidal mechanism may be achieved by damaging the bacterial cell membrane [27].

To verify our conjecture, the membrane disruption action of compound 7 against MRSA-3 was investigated by fluorescence probe SYTOX Green and PI, as well as fluorescence imaging technology. As a result, both assays presented the same results, showing that compound 7 could rapidly kill the bacteria by disrupting the cell membranes.

Antibiotic resistance is a highlighted problem that has attracted global attention. Many new and promising antibacterial candidates are being designed for targeting the bacterial cell membrane because of their low-frequency drug resistance and potential to rapidly kill bacteria [28], but their potential cytotoxicity to the host is still a matter of considerable debate [29]. In this case, the $\mathrm{HC}_{50}$ of compounds 6 and 7 against RBCs was approximately $32 \mu \mathrm{g} / \mathrm{mL}$, which yielded an initial therapeutic index of $2-8 \mu \mathrm{g} / \mathrm{mL}$ towards MRSA. Despite this, the structural optimization of both compounds to reduce toxicity still needs to be further explored.

In conclusion, our present results detail three new terpenoids and two potent in vitro antibacterial constitutions in the stems and leaves of I. simonsii extract; moreover, compounds 6 and 7 may represent promising natural antibacterial compounds for developing new anti-infectious drugs, although their exact mechanism of action and pharmacological action in vivo remain to be clarified.

\section{Material and Methods}

\subsection{General Experimental Procedures}

Ultraviolet (UV) spectra and infrared (IR) spectra (KBr) were evaluated on a Shimadzu UV2401PC spectrophotometer (Shimadzu, Kyoto, Japan) and Bio-Rad FTS-135 spectrometer (Hercules, CA, USA), respectively. NMR spectra were obtained on DRX-400 or Advance III-600 spectrometers (Bruker, Bremerhaven, Germany) with TMS as the internal standard. Optical rotations were recorded on a JASCO P-1020 polarimeter (Horiba, Tokyo, Japan). The high-resolution mass spectra A were conducted on a Shimadzu LCMS-IT-TOF mass spectrometer (Shimadzu, Kyoto, Japan). Silica gel (100-200, 200-300 mesh, Qingdao Meigao Chemical Company, Qingdao, China), Sephadex LH-20 (20-150 m, Amersham Pharmacia Biotech AB, Uppsala, Sweden.) and semi-preparative RP-HPLC purification (LC-20AT Shimadzu liquid chromatography system with ChromCoreTMC18 semi-preparative column, $250 \mathrm{~mm} \times 10 \mathrm{~mm}, 5 \mu \mathrm{m}$ ) were used. Thin-layer chromatography (TLC) was conducted and detected under UV light or by heating after spraying with $10 \% \mathrm{H}_{2} \mathrm{SO}_{4}$. Optical density and fluorescence were measured by a Microplate Reader (Tecan Infnite Pro series M200). A Nikon ECLIPSE 80i was used to perform the fluorescence experiments. 


\subsection{Plant Material, Separation and Purification of Compounds 1-11}

The stems and leaves of the plant were collected in Dali City, Yunnan Province, China, during August 2015 and identified as Illicium simonsii Hook. f. et Thoms. by Prof. Dequan Zhang (College of Pharmacy, Dali University). A voucher specimen of I. simonsii (2 August 2015) was deposited at the School of Pharmaceutical Science, Zhengzhou University.

The powdered stems and leaves of I. simonsii $(15.0 \mathrm{~kg})$ were extracted with $95 \% \mathrm{EtOH}$ $(35 \mathrm{~L} \times 2)$ under reflux for $3 \mathrm{~h}$ each time. After removal of solvent, the EtOH extract was suspended in $\mathrm{H}_{2} \mathrm{O}$ and then extracted with $\mathrm{CH}_{2} \mathrm{Cl}_{2}(5 \mathrm{~L} \times 3)$ to give a $\mathrm{CH}_{2} \mathrm{Cl}_{2}$ fraction (300 g). The $\mathrm{CH}_{2} \mathrm{Cl}_{2}$ fraction was loaded onto a silica gel $\left(\mathrm{CH}_{2} \mathrm{Cl}_{2}-\mathrm{MeOH}, 100: 1\right.$ to 80:20) and yielded seven fractions (Frs. 1-7). Fr. 4 (10 g) exhibited antibacterial activity with $\mathrm{MIC}=128 \mu \mathrm{g} / \mathrm{mL}$. Fr. 4 was further purified by repeated chromatography (including semi-preparative HPLC, silica gel, MCI gel, and Sephadex LH-20 gel) to obtain compounds 1 (4 mg), 2 (6 mg), 3 (15 mg), 4 (8 mg), 5 (16 mg), 6 (7 mg), 7 (15 mg), 8 (17 mg), 9 (23 mg), $10(6 \mathrm{mg})$ and $11(20 \mathrm{mg})$.

1-Ethoxycaryolane-1, $9 \beta$-diol (1). Colorless gum; $[\alpha]_{\mathrm{D}}^{24.8}+10.6$ (c 0.180, MeOH); UV $(\mathrm{MeOH}): \lambda_{\max }(\log \varepsilon)=196(3.29) \mathrm{nm} ; \mathrm{IR}(\mathrm{KBr}): \nu_{\max }=3416,2931,2867,1061,1027 \mathrm{~cm}^{-1} ;{ }^{1} \mathrm{H}$, ${ }^{13} \mathrm{C}-\mathrm{NMR}$ : Table 1; HR-ESI-MS: $m / z=289.2144$ [M+Na] ${ }^{+}$(calcd. for $\mathrm{C}_{17} \mathrm{H}_{30} \mathrm{O}_{2} \mathrm{Na}$ : 289.2144). 2-Ethoxyclovane-2 $\beta, 9 \alpha$-diol (3). Colorless gum; $[\alpha]_{\mathrm{D}}^{25.1}+5.42(c 0.200, \mathrm{MeOH}) ; \mathrm{UV}$ $(\mathrm{MeOH}): \lambda_{\max }(\log \varepsilon)=196(3.23) \mathrm{nm} ; \mathrm{IR}(\mathrm{KBr}): v_{\max }=3382,2931,1112,1075 \mathrm{~cm}^{-1} ;{ }^{1} \mathrm{H}$,

${ }^{13} \mathrm{C}-\mathrm{NMR}$ : Table 1; HR-ESI-MS: $m / z=289.2136[\mathrm{M}+\mathrm{Na}]^{+}$(calcd. for $\mathrm{C}_{17} \mathrm{H}_{30} \mathrm{O}_{2} \mathrm{Na}$ : 289.2138). p-Menthane-1 $\alpha, 2 \alpha, 8$-triol-4-O- $\beta$-D-glucoside (5). Colorless gum; $[\alpha]_{\mathrm{D}}^{19.1}-16.26$ (c 0.108, $\mathrm{MeOH}) ; \mathrm{UV}(\mathrm{MeOH}): \lambda_{\max }(\log \varepsilon)=196$ (3.63) nm; IR $(\mathrm{KBr}): v_{\max }=3417,2924,1073$, $1038 \mathrm{~cm}^{-1} ;{ }^{1} \mathrm{H},{ }^{13} \mathrm{C}-\mathrm{NMR}$ : Table 2; HR-ESI-MS: $m / z=389.1744[\mathrm{M}+\mathrm{Na}]^{+}$(calcd. for $\left.\mathrm{C}_{16} \mathrm{H}_{30} \mathrm{O}_{9} \mathrm{Na}: 389.1789\right)$.

\subsection{Antibacterial Assays}

\subsubsection{Bacterial Strains and Growth Condition}

Staphylococcus aureus (ATCC 29213), Enterococcus faecalis (ATCC 29212), Bacillus subtilis (ATCC 6633) and Escherichia coli (ATCC 25922) were purchased from the American Type Culture Collection. The methicillin-resistant $S$. aureus (MRSA-1-10) was provided by the First Affiliated Hospital of Zhengzhou University. The bacterial strains were stored in a refrigerator at $-80^{\circ} \mathrm{C}$. Before the experiment, the experimental strains were thawed and inoculated on a MHA nutrient agar plate. After being cultured overnight at $37^{\circ} \mathrm{C}$, the strain was picked up into $1 \mathrm{~mL}$ MHB culture medium, and incubated in a $37^{\circ} \mathrm{C}$ shaker at $200 \mathrm{rpm}$ for $3-5 \mathrm{~h}$.

\subsubsection{Antimicrobial Activity by K-B Disk Diffusion Test}

The antimicrobial activity of the $I$. simonsii extract was carried out by the disc diffusion method according the literature [30]. Briefly, the test sample was first dissolved with DMSO to obtain a concentration of $1280 \mu \mathrm{g} / \mathrm{mL}$ solution, the inoculums of microorganisms were spread over nutrient agar plates with a sterile swab, and sterilized metrical filter paper discs were soaked with $10 \mu \mathrm{g} /$ disc concentration of the test samples. Then, the soaked discs were placed on the marked agar plate and dried and inoculated at $37^{\circ} \mathrm{C}$ for $16-18 \mathrm{~h}$. Vancomycin was used as a positive control. The diameters of inhibition zones were measured.

\subsubsection{Minimum Inhibitory Concentration (MIC) Assay}

The MIC values of compounds 1-11 were determined by broth micro-dilution in a Mueller-Hinton broth medium (MHB) according to the guidelines of the Clinical and Laboratory Standards Institute [31]. S. aureus (ATCC 29213), E. coli (ATCC 25922) and clinical MRSA strains (M-1-10) were used in this experiment. Test compounds were dissolved into DMSO, and antibiotic vancomycin was dissolved with sterile Milli-Q water, then these solutions were two-fold serially diluted to a series of gradient concentrations $(256,128,64,32,16,8,4,2$, and $1 \mu \mathrm{g} / \mathrm{mL})$. The results were determined after incubation for 16-18 $\mathrm{h}$ at $37^{\circ} \mathrm{C}$. The MIC was defined as the lowest concentration of the compound that 
produced complete inhibition of visible growth. All MIC determinations were repeated three times.

\subsubsection{Time-Kill Kinetics Assay}

A time-kill assay was evaluated according to the guidelines of CLSI [31]. Briefly, an overnight culture of bacterial (MRSA-3) was adjusted in Mueller-Hinton broth (MHB) medium to obtain a bacterial suspension with $10^{5}$ (early exponential phase) and $10^{8}$ (stationary exponential phase) CFU / mL. Then, MASR-3 was challenged with compound 6 $(1 \times, 2 \times$ and $4 \times \mathrm{MIC}), 7(1 \times, 2 \times$ and $3 \times \mathrm{MIC})$ and vancomycin $(3 \times \mathrm{MIC}, 4 \times \mathrm{MIC})$ at $37^{\circ} \mathrm{C}$ and $225 \mathrm{rpm}$. The aliquots were removed at $0 \mathrm{~h}, 1 \mathrm{~h}, 2 \mathrm{~h}, 4 \mathrm{~h}, 6 \mathrm{~h}$, and $8 \mathrm{~h}$, serial 10-fold dilutions of the sample were made in the diluent (PBS), and a $10 \mu \mathrm{L}$ aliquot of each dilution was plated out on MHA plates using the surface-spread plate method. The plates were incubated at $37^{\circ} \mathrm{C}$ for $24 \mathrm{~h}$ to measure viable plate counts (CFU).

\subsubsection{Bacteria Resistance Study}

According to the methods used in previous studies [32], the propensity for developing bacterial resistance towards S. aureus (ATCC 29213) of compounds 6, 7 and control antibiotic norfloxacin was investigated. Briefly, the original MICs of compounds 6, 7 and norfloxacin against $S$. aureus were determined at first. An $S$. aureus suspension incubated at the exponential phase at $37^{\circ} \mathrm{C}$ was passaged to a fresh $\mathrm{MHB}$ containing the test compounds at sub-inhibitory concentration (1/2 MIC), the process was repeated every 20 to $22 \mathrm{~h}$ for up to 20 passages, and the MICs for test compounds were assayed at every passage as described above.

\subsubsection{Hemolytic Activity}

Red blood cells (RBCs), isolated from the fresh sterile sheep blood, were resuspended in $1 \times$ PBS $(5 \%)$. A RBCs suspension $(150 \mu \mathrm{L})$ was then added to solutions of serially diluted compounds 6 and 7 at the different concentrations (compound 6 for $1 / 16 \times, 1 / 8 \times, 1 / 4 \times$, $1 / 2 \times, 1 \times, 2 \times, 4 \times, 8 \times$ MIC; compound 7 for $1 / 4 \times, 1 / 2 \times, 1 \times, 2 \times, 4 \times$ MIC) in a 96 -well plate $(50 \mu \mathrm{L})$. Triton $\mathrm{X}-100(1 \%)$ was used as a positive control. The plate was incubated for $1 \mathrm{~h}$ at $37^{\circ} \mathrm{C}$ and centrifuged at $3500 \times g$ rpm for $5 \mathrm{~min}$. The supernatant $(100 \mu \mathrm{L})$ was transferred to a fresh 96-well plate. The results are shown as the percentage of hemolysis according to the absorbance measured at $540 \mathrm{~nm}$ [33].

\subsection{Investigation of Antibacterial Mechanism}

\subsubsection{SYTOX Green Staining Assay}

The bacterial suspension of MRSA-3 was incubated at $37^{\circ} \mathrm{C}$ for $6 \mathrm{~h}$ and suspended in $1 \times$ PBS. Then, the bacterial suspension was incubated with $3 \mu \mathrm{M}$ of SYTOX green for $20 \mathrm{~min}$ at room temperature until the fluorescence readings were stable. The final concentrations of added compound 7 were $1 / 4 \times \mathrm{MIC}, 1 / 2 \times \mathrm{MIC}, 1 \times \mathrm{MIC}, 2 \times \mathrm{MIC}, 4 \times \mathrm{MIC}$, and $8 \times \mathrm{MIC}$. The fluorescence reading was monitored for the next $40 \mathrm{~min}$ at every $2 \mathrm{~min}$ interval at an excitation wavelength of $504 \mathrm{~nm}$ and an emission wavelength of $523 \mathrm{~nm}$. Vancomycin and daptomycin were used as negative controls, and melittin was used as a positive control. DMSO $(100 \%, 1 \%)$ and water were used as blank controls.

\subsubsection{Visualization of Bacterial Membrane Permeability}

As described in the literature [34], the bacterial suspension of MRSA-3 was treated with compound 7 at desired concentrations $\left(2 \times\right.$ and $4 \times$ MIC). After incubation at $37{ }^{\circ} \mathrm{C}$ for $3 \mathrm{~h}$, the bacterial suspension was added and stained with $4^{\prime}$, 6-diamidino-2-phenylindole dihydrochloride (DAPI, $10 \mu \mathrm{g} / \mathrm{mL}$ ) and propidium iodide (PI, $20 \mu \mathrm{g} / \mathrm{mL}$ ) for $30 \mathrm{~min}$ at $0{ }^{\circ} \mathrm{C}$. Finally, the suspension was observed by a fluorescence microscope with an excitation wavelength of $485 \mathrm{~nm}$. Bacterial no-treatment with 7 was used as a blank control. 
Supplementary Materials: The following supporting information can be downloaded: Page S2-S13: ${ }^{1} \mathrm{H}$ NMR, ${ }^{13} \mathrm{C}$ NMR, DEPT-90, DEPT-135, HSQC, HMBC, COSY, ROESY, HRESI, IR (KBr) and UV spectrum of compound 1; Page S14-S25: ${ }^{1} \mathrm{H}$ NMR, ${ }^{13} \mathrm{C}$ NMR, DEPT-90, DEPT-135, HSQC, HMBC, COSY, ROESY, HRESI, IR (KBr) and UV spectrum of compound 3; Page S26-S36: ${ }^{1} \mathrm{H}$ NMR, ${ }^{13} \mathrm{C}$ NMR, DEPT-90, DEPT-135, HSQC, HMBC, COSY, ROESY, HRESI, IR (KBr) and UV spectrum of compound 5; Page S37-S39: Spectroscopic data of compounds 2, 4 and 6-11. Page S40: K-B disk diffusion test of I. simonsii extract against S. aureus, B. subtilis and E. faecalis.

Author Contributions: Performed the experiments, H.L. (Huijuan Li); anti-MRSA analysis, X.S. and L.Z.; original draft preparation, H.L. (Huijuan Li) and J.L.; review and editing, H.L. (Huirui Li), supervision and visualization, J.L. and S.C. All authors have read and agreed to the published version of the manuscript.

Funding: This research was supported by the National Natural Science Foundation of China (U1904136) and the Science and Technology Tackling Project of Henan Science and Technology Department (No. 182102310063).

Institutional Review Board Statement: Not applicable.

Informed Consent Statement: Not applicable.

Data Availability Statement: All data are available in this publication and in the Supplementary Materials.

Conflicts of Interest: The authors declare no conflict of interest.

Sample Availability: Samples of the compounds are available from the authors.

\section{References}

1. Richter, M.F.; Drown, B.S.; Riley, A.P.; Garcia, A.; Shirai, T.; Svec, R.L.; Hergenrother, P.J. Predictive compound accumulation rules yield a broad-spectrum antibiotic. Nature 2017, 545, 299-304. [CrossRef] [PubMed]

2. $\quad$ O'Connell, K.M.G.; Hodgkinson, J.T.; Sore, H.F.; Welch, M.; Salmond, G.P.C.; Spring, D.R. Combating multidrug-resistant bacteria: Current strategies for the discovery of novel antibacterials. Angew. Chem. Int. Ed. 2013, 52, 10706-10733. [CrossRef] [PubMed]

3. Lee, C. Therapeutic challenges in the era of antibiotic resistance. Int. J. Antimicrob. Ag. 2008, 32, S197-S199. [CrossRef]

4. Howden, B.P.; Grayson, M.L. Dumb and dumber-the potential waste of a useful antistaphylococcal agent: Emerging fusidic acid resistance in Staphylococcus aureus. Clin. Infect. Dis. 2006, 42, 394-400. [CrossRef]

5. Zhang, D.Y.; Wang, X.X.; Zhuang, P.Y.; Feng, Y.J.; Jin, X.Y. Sesquiterpenoids and lignans from the fruits of Illicium simonsii Maxim. Biochem. Syst. Ecol. 2019, 83, 47-50. [CrossRef]

6. Chu, S.S.; Liu, S.L.; Jiang, G.H.; Liu, Z.L. Composition and toxicity of essential oil of Illicium simonsii Maxim (Illiciaceae) fruit against the maize weevils. Rec. Nat. Prod. 2010, 4, 205-210.

7. Wei, D.D.; Wang, J.S.; Kong, L.Y. Reversal effects of components from the fruits of Illicium simonsii on human adriamycin-resistant MCF-7 and 5-fluorouracil-resistant Bel7402 cells. Phytother. Res. 2012, 26, 562-567. [CrossRef]

8. Guo, Y.; Bao, C.N.; Li, F.; Hou, E.H.; Qin, S.S.; Zhang, Q.R.; Liu, J.F. Discovery, synthesis, and biological evaluation of dunnianolbased mannich bases against methicillin-resistant Staphylococcus Aureus (MRSA). ACS Infect. Dis. 2020, 6, 2478-2489. [CrossRef] [PubMed]

9. Guo, Y.; Yang, R.; Chen, F.; Yan, T.; Wen, T.; Li, F.; Su, X.; Wang, L.; Du, J.; Liu, J. Triphenyl-sesquineolignan analogues derived from Illicium simonsii Maxim exhibit potent antibacterial activity against methicillin-resistant Staphylococcus aureus (MRSA) by disrupting bacterial membranes. Bioorganic. Chem. 2021, 110, 104824. [CrossRef]

10. Liu, J.F.; Zhang, X.M.; Shi, Y.; Zhang, Q.; Ma, Y.B.; Chen, J.J. Chemical constituents in stems and leaves of Illicium simonsii. Chin. Tradit. Herbal Drugs 2012, 43, 51-54.

11. Heymann, H.; Tezuka, Y.; Kikuchi, T.; Supriyatna, S. Constituents of Sindora sumatrana MIQ.I. isolation and NMR spectral analysis of sesquiterpenes from the dried pods. Chem. Pharm. Bull. 1994, 42, 138-146. [CrossRef]

12. Liu, J.F.; Li, H.J.; Yang, L.J.; Liu, M.Q.; Bi, Y.F.; Zhang, Y.B. Two new monoterpenes from the fruits of Illicium lanceolatum. Molecules 2013, 18, 11866-11872. [CrossRef]

13. Cheng, M.J.; Lo, W.L.; Huang, J.C.; Yeh, Y.T.; Hong, Z.L.; Lu, Y.C.; Chang, M.S.; Chen, C.Y. Isolation of a new monoterpenic ester from the leaves of Michelia compressa (Maxim.) Sargent var. formosana Kanehira (Magnoliaceae). Nat. Prod. Res. 2010, 24, 682-686. [CrossRef]

14. Hu, Y.M.; Yang, Z.L.; Ye, W.C.; Cheng, Q.H. Studies on the constituents in rhizome of Homalomena occuta. Chin. J. Chin. Mater. Med. 2003, 28, 342-344.

15. Liu, C.M.; Zhou, H.B.; Zhang, W.D. Terpenoids from stems and leaves of Cupressus gigantea. Chin. J. Nat. Med. 2010, 8, 0405-0410. [CrossRef]

16. Liu, X.; Xu, W.; Yang, X.; Zhang, P.; Zhao, W.; Gong, Y.; Liu, N. Study on non-flavonoids chemical constituents from Spatholobi Caulis. Chin. J. Chin. Mater. Med. 2020, 45, 1120-1127. 
17. Park, J.H.; Lee, D.G.; Yeon, S.W.; Kwon, H.S.; Ko, J.H.; Shin, D.J.; Park, H.S.; Kim, Y.S.; Bang, M.H.; Baek, N.I. Isolation of megastigmane sesquiterpenes from the Silkworm (Bombyx mori L.) droppings and their promotion activity on HO-1 and SIRT1. Arch. Pharm. Res. 2011, 34, 533-542. [CrossRef] [PubMed]

18. Berney, M.; Hammes, F.; Bosshard, F.; Weilenmann, H.U.; Egli, T. Assessment and interpretation of bacterial viability by using the LIVE/DEAD BacLight kit in combination with flow cytometry. Appl. Environ. Microbiol. 2007, 73, 3283-3290. [CrossRef] [PubMed]

19. Dzamic, A.; Sokovic, M.; Ristic, M.S.; Grijic-Jovanovic, S.; Vukojevic, J.; Marin, P.D. Chemical composition and antifungal activity of Illicium verum and Eugenia caryophyllata essential oils. Chem. Nat. Compd. 2009, 45, 259-261. [CrossRef]

20. Vijayakumar, A.; Duraipandiyan, V.; Jeyaraj, B.; Agastian, P.; Raj, M.K.; Ignacimuthu, S. Phytochemical analysis and in vitro antimicrobial activity of Illicium griffithii Hook. f. \& Thoms extracts. Asian Pac. J. Trop. Dis. 2012, 2, 190-199.

21. Min, Y.; Zhang, W.; Yang, J.; Liu, W. Chemical composition and antimicrobial activity of volatile components from wild Illicium wardii in China. Adv. Mat. Res. 2011, 239-242, 3367-3370. [CrossRef]

22. Szymulanska-Ramamurthy, K.M.; Zhao, M.; Che, C.T. Phytochemical study of Illicium angustisepalum and its biological activities. Acta Pharm. Sin. B 2017, 7, 485-490. [CrossRef]

23. Liu, J.F.; Jiang, Z.Y.; Geng, C.A.; Zou, X.B.; Shi, Y.; Ma, Y.B.; Zhang, X.M.; Chen, J.J. Two new phenylpropanoid derivatives and other constituents from Illicium simonsii active against oral microbial organisms. Planta Med. 2010, 76, 1464-1467. [CrossRef] [PubMed]

24. Setzer, W.N.; Setzer, M.C.; Bates, R.B.; Nakkiew, P.; Jackes, B.R.; Chen, L.; McFerrin, M.B.; Meehan, E.J. Antibacterial hydroxycinnamic esters from Piper caninum from Paluma, North Queensland, Australia. The crystal and molecular structure of (+)-bornyl coumarate. Planta Med. 1999, 65, 747-749. [CrossRef]

25. e Silva, A.T.M.; Pereira, V.V.; Takahashi, J.A.; Silva, R.R.; Duarte, L.P. Microwave-assisted synthesis of borneol esters and their antimicrobial activity. Nat. Prod. Res. 2018, 32, 1714-1720. [CrossRef]

26. Konuk, H.B.; Ergüden, B. Phenolic-OH group is crucial for the antifungal activity of terpenoids via disruption of cell membrane integrity. Folia Microbiol. 2020, 65, 775-783. [CrossRef]

27. Epand, R.M.; Vogel, H.J. Diversity of antimicrobial peptides and their mechanisms of action. Biochim. Et Biophys. Acta (BBA)-Biomembr. 1999, 1462, 11-28. [CrossRef]

28. Epand, R.M.; Walker, C.; Epand, R.F.; Magarvey, N.A. Molecular mechanisms of membrane targeting antibiotics. Biochim. Biophys. Acta (BBA)-Biomembr. 2016, 1858, 980-987. [CrossRef]

29. Kim, W.; Zhu, W.; Hendricks, G.L.; Tyne, T.D.; Steele, A.D.; Keohane, C.E.; Fricke, N.; Conery, A.L.; Shen, S.; Pan, W.; et al. A new class of synthetic retinoid antibiotics effective against bacterial persisters. Nature 2018, 556, 103-107. [CrossRef]

30. Drew, W.L.; Barry, A.L.; Toole, R.; Sherris, J.C. Reliability of the Kirby-Bauer disc diffusion method for detecting methicillinresistant strains of Staphylococcus aureus. Appl. Microbiol. 1972, 24, 240-247. [CrossRef] [PubMed]

31. Patel, J.B.; Weinstein, M.P.; Eliopoulos, G.M.; Jenkins, S.G.; Lewis, J.S.; Limbago, B.; Mathers, A.J.; Mazzulli, T.; Patel, R.S.; Richter, S.; et al. Performance Standards for Antimicrobial Susceptibility Testing: Twenty-Seventh Informational Supplement M100-S27; Clinical and Laboratory Standards Institute: Wayne, PA, USA, 2017.

32. Guo, Y.; Xu, T.; Bao, C.; Liu, Z.; Fan, J.; Yang, R.; Qin, S. Design and synthesis of new norfloxacin-1, 3, 4-oxadiazole hybrids as antibacterial agents against methicillin-resistant Staphylococcus aureus (MRSA). Eur. J. Pharm. Sci. 2019, 136, 104966. [CrossRef] [PubMed]

33. Konai, M.M.; Haldar, J. Fatty acid comprising lysine conjugates: Anti-MRSA agents that display in vivo efficacy by disrupting biofilms with no resistance development. Bioconjug. Chem. 2017, 28, 1194-1204. [CrossRef] [PubMed]

34. Huang, L.; Chen, D.; Wang, L.; Lin, C.; Ma, C.; Xi, X.; Chen, T.; Shaw, C.; Zhou, M. Dermaseptin-PH: A novel peptide with antimicrobial and anticancer activities from the skin secretion of the South American orange-legged leaf frog, Pithecopus (phyllomedusa) hypochondrialis. Molecules 2017, 22, 1805. [CrossRef] [PubMed] 